STUDIA Z PRAWA WYZNANIOWEGO

Tom $24-2021$

DOI: https://doi.org/10.31743/spw.12720

ANETA M. ABRAMOWICZ*

\title{
WOLNOŚĆ RELIGIJNA \\ W CZASIE PANDEMII KORONAWIRUSA - OCENA ROZWIĄZAŃ POLSKICH
}

Religious freedom during the coronavirus pandemic:

An assessment of the Polish legal solutions

Streszczenie: Zagrożenie z powodu rozprzestrzeniania się koronawirusa w Polsce spowodowało wprowadzenie w marcu 2020 r. stanu zagrożenia epidemicznego, a następnie stanu epidemii na terenie całego kraju. Właściwe organy władzy państwowej wprowadziły liczne ograniczenia poszczególnych praw i wolności człowieka, w tym również wolności uzewnętrzniania religii. Polski prawodawca $\mathrm{w}$ art. 31 ust. 3 i art. 53 ust. 5 Konstytucji RP określił zasady dotyczące możliwości wprowadzenia dozwolonych ograniczeń tej wolności. Ograniczenia takie zgodnie z przepisami konstytucyjnymi mogą być wprowadzone tylko w ustawie i w sytuacji, gdy są konieczne w społeczeństwie demokratycznym z powodu ochrony dóbr szczególnie chronionych. Muszą być proporcjonalne tak, aby nie naruszać samej istoty ograniczanego prawa. Wprowadzone ograniczenia dotyczące możliwości uczestniczenia i sprawowania kultu religijnego budzą wątpliwości co do ich legalności i konstytucyjności. Zagrożenie epidemiczne uzasadnia podejmowanie działań ze strony właściwych organów władzy państwowej w celu zapewnienia bezpieczeństwa, jednak organy te powinny działać na podstawie i w granicach prawa. Przepisy konstytucyjne nie pozostawiają dowolności w zakresie możliwości wprowadzania ograniczeń praw i wolności człowieka, w tym również prawa do wolności religii.

* Dr, Katedra Prawa Wyznaniowego, Wydział Prawa, Prawa Kanonicznego i Administracji, Katolicki Uniwersytet Lubelski Jana Pawła II, Al. Racławickie 14, 20-950 Lublin, e-mail: aneta.abramowicz@kul.pl. ORCID 0000-0002-1601-6969. 
Słowa kluczowe: wolność religijna; wolność uzewnętrzniania religii; ograniczenia wolności uzewnętrzniania religii; Trybunał Konstytucyjny; Europejski Trybunał Praw Człowieka

Abstract: The threat posed by the spread of coronavirus in Poland resulted in the introduction of the state of epidemic emergency for the whole country in March 2020 , subsequently followed by the state of epidemic. The competent state authorities have introduced numerous limitations on individual human rights and freedoms, including limitations on the freedom to manifest religion. The Polish legislator laid down the principles for permissible limitations on this freedom in Articles 31(3) and 53(5) of the Constitution of the Republic of Poland. In accordance with the constitutional provisions, such limitations may only be introduced by statutory acts and in situations when they are necessary in a democratic society for the protection of specially protected goods. They must be proportionate so as not to impair the very essence of the right being limited. The introduced limitations on participating in and performing religious worship raise doubts as to their legality and constitutionality. The epidemic threat justifies taking action by competent state authorities to ensure safety. However, state authorities should act on the basis and within the limits of the law. The constitutional provisions do not leave any room for discretion as regards the possibility of introducing limitations on human rights and freedoms, including the right to freedom of religion.

Key words: religious freedom; freedom to manifest religion; limitations on the freedom to manifest religion; Constitutional Court; European Court of Human Rights

\section{WPROWADZENIE}

Zagrożenie wywołane rozprzestrzenianiem się koronawirusa w Polsce stało się powodem wprowadzenia w marcu 2020 r. stanu zagrożenia epidemicznego, a następnie stanu epidemii na terenie całego kraju. Konsekwencją tego było wprowadzanie przez właściwe organy władzy państwowej licznych ograniczeń poszczególnych praw i wolności człowieka, w tym również wolności sumienia i religii, która jest jedną z podstawowych wolności człowieka. Jest ona jednym z fundamentów pluralistycznego społeczeństwa demokratycznego. Stanowi jeden z najistotniejszych elementów składających się na tożsamość wyznawców, ich koncepcję życia, ale również ma ogromne znaczenie dla osób, których światopogląd nie opiera się 
na wierze religijnej ${ }^{1}$. Władze publiczne zobowiązane są do zabezpieczenia tej wolności przed nielegalną ingerencją wyłączającą lub zakłócającą możliwość korzystania z tej wolności².

$\mathrm{W}$ miarę rozwoju zagrożenia z powodu rozprzestrzeniania się koronawirusa dokonywano kolejnych zmian aktów prawnych wprowadzających ograniczenia poszczególnych praw i wolności człowieka. Podjęte rozważania mają na celu wskazanie unormowanych ograniczeń wolności uzewnętrzniania religii i ich zmian. Zostaną one rozpoczęte od przedstawienia konstytucyjnych wymogów dotyczących możliwości wprowadzenia dozwolonych ograniczeń wolności uzewnętrzniania religii, a w dalszej części zostaną wskazane akty prawne wydane przez właściwe organy władzy publicznej wprowadzające ograniczenia tej wolności. Przedstawienie tych kwestii pozwoli w końcowej części opracowania na sformułowanie oceny obowiązujących obecnie przepisów prawnych dotyczących możliwości wprowadzenia ograniczeń wolności uzewnętrzniania religii w Polsce i podjęcia refleksji nad zaistniałymi problemami prawnymi.

\section{ZASADY WPROWADZANIA DOZWOLONYCH OGRANICZEŃ WOLNOŚCI UZEWNĘTRZNIANIA RELIGII}

Polski porządek prawny chroni wolność religijną zarówno w aspekcie wewnętrznym, jak i zewnętrznym. Jednak w szczególnych sytuacjach dopuszcza się wprowadzenie ograniczeń wolności religii, ale jedynie w zakresie jej uzewnętrzniania. Wówczas możemy mieć do czynienia z wolnością prawnie ograniczaną. Może istnieć tu sfera działań prawem nakazanych lub zakazanych $\mathrm{w}$ akcie prawnym ustanawiającym granice wolności religii ${ }^{3}$. Zatem wolność ta nie ma charakteru absolutnego i może doznawać pewnych ograniczeń. Jednak te ograniczenia nie mogą być nad-

1 Zob. wyrok ETPC z dnia 25 maja 1993 r., Kokkinakis v. Grecja, skarga nr 14307/88, http://www.bailii.org/eu/cases/ECHR/1993/20.html [dostęp: 09.11.2021]. Karpiuk 2017, 9; McCrea 2010, 121-135; Abramowicz 2015, 14.

Karpiuk 2017, 5.

3 Zob. Warchałowski 2004, 144. 
mierne i wprost powinny mieć na celu ochronę poszczególnych wartości konstytucyjnych ${ }^{4}$.

Kryteria dopuszczalności wprowadzenia ograniczeń wolności uzewnętrzniania religii zostały określone w art. 53 ust. 5 Konstytucji RP ${ }^{5}$. Ich wprowadzenie możliwe jest jedynie w ustawie i tylko wtedy, gdy jest to konieczne dla ochrony bezpieczeństwa państwa, porządku publicznego, zdrowia, moralności oraz wolności i praw innych osób. Stanowią one swoiste granice swobodnej sfery działania człowieka w zakresie korzystania z wolności religii. Ma to zapobiec niewłaściwemu korzystaniu z wolności religii, co mogłoby naruszać sferę wolności innych ludzi i całego społeczeństwa ${ }^{6}$.

Omawiając zagadnienie dozwolonych ograniczeń wolności uzewnętrzniania religii należy odnieść się również do art. 31 ust. 3 Konstytucji RP, który określa ogólne zasady obowiązujące przy wprowadzaniu ograniczeń dotyczących korzystania z konstytucyjnych wolności i praw człowieka. Natomiast art. 53 ust. 5 Konstytucji RP w sposób szczególny ma zastosowanie do ograniczeń wolności uzewnętrzniania religii ${ }^{7}$. Przesłanki wymienione w art. 31 ust. 3 to: ustawowa forma wprowadzenia ograniczenia, konieczność wprowadzenia w państwie demokratycznym takiego ograniczenia, funkcjonalny związek pomiędzy wprowadzonym ograniczeniem a zabezpieczeniem wymienionych w tym przepisie dóbr oraz zakaz naruszania istoty ograniczanego prawa lub wolności człowieka ${ }^{8}$.

Istotną przesłanką unormowaną w art. 53 ust. 5 jest wymóg ustanawiania ograniczeń wolności uzewnętrzniania religii w akcie prawnym o randze ustawowej. Wyklucza to możliwość wykorzystywania w tym celu

4 Karpiuk 2017, 6; Ożóg 2015, 104.

5 Konstytucja Rzeczypospolitej Polskiej z dnia 2 kwietnia 1997 r., Dz. U. z 1997 r. Nr 78, poz. 483 z późn. zm.

6 Pietrzak 2013, 36.

7 Jednak nie wszystkie przesłanki uzasadniające wprowadzenie dozwolonych ograniczeń praw i wolności człowieka określone w art. 31 ust. 3 mogą być zastosowane w odniesieniu do wolności uzewnętrzniania religii. Wyjątek stanowi przesłanka ochrony środowiska. Stanisz 2017, 47-48; Karpiuk 2017, 16; Ożóg 2015, 108; Olszówka, Dyda 2020, 450. Odmienna teza zawarta jest w wyroku Trybunału Konstytucyjnego z dnia 10 grudnia 2014 r., K 52/13, OTK-A 2014, Nr 11, poz. 118.

8 Karpiuk 2017, 13-14; Kazimierczuk 2014, 103-104; Morawski 2020, 9. 
rozporządzenia czy też zarządzenia wydawanego przez organy władzy wykonawczej oraz organy administracyjne ${ }^{9}$. Dlatego, aby nie dochodziło do nadużyć w zakresie korzystania z praw i wolności jednostki, powinny być wydawane odpowiednie przepisy prawne, ponieważ nawet w czasie zagrożenia działania organów władzy publicznej powinny mieć podstawę prawną ${ }^{10}$. Zatem granice ingerencji w sferę wolności i praw człowieka powinna określać norma prawna, która musi wynikać z ustawy, czyli jak na to zwrócił uwagę Trybunał Konstytucyjny w orzeczeniu z dnia 20 lipca 2006 r. ${ }^{11}$ ingerencja taka musi wynikać wprost z przepisu i nie może opierać się na domniemaniu ${ }^{12}$.

Aby uznać, że dane ograniczenie wolności uzewnętrzniania religii zostało wprowadzone przez akt prawny legalnie, pomocnym jest sięgnięcie do orzecznictwa Europejskiego Trybunału Praw Człowieka (ETPC). Można odnaleźć tam trzy warunki legalności właściwego uchwalania aktów prawnych. Po pierwsze akt prawny ma być dostatecznie dostępny, czyli każdy w swobodny sposób może zapoznać się z normami tego aktu. Po drugie prawo musi być wystarczająco precyzyjne, czyli takie, aby jednostka mogła rozeznać, jakie zachowanie jest sprzeczne z przepisem prawa oraz aby mogła przewidzieć konsekwencje konkretnego działania. Natomiast po trzecie akt prawny powinien jasno i precyzyjnie określać zakres uprawnień dyskrecjonalnych kompetentnych organów władzy oraz sposób korzystania z nich. W ten sposób zabezpiecza się jednostkę przed ingerencją państwa ${ }^{13}$.

Wprowadzane ograniczenia wolności uzewnętrzniania religii muszą być proporcjonalne. Zasada proporcjonalności pozwala na rozstrzygnięcie kolizji pomiędzy kilkoma prawami chronionymi konstytucyjnie. Zasada ta zakłada konieczność wprowadzenia ograniczenia prawa w ustawie oraz wykazania uzasadnienia wprowadzenia tego ograniczenia w celu ochrony enumeratywnie wymienionych przesłanek w art. 31 ust. 3, ale również w art. 53 ust. 5 Konstytucji RP. Zgodnie z orzeczeniem TK

9 Pietrzak 2013, 37.

10 Karpiuk 2017, 10.

11 Orzeczenie Trybunału Konstytucyjnego z dnia 20 lipca 2006 r., K 40/05, OTK-A 2006, Nr 1, poz. 4.

12 Ruczkowski 2012, 79-80.

13 Warchałowski 2004, 153. 
z dnia 23 listopada 2009 r. ${ }^{14}$ ocena spełnienia przesłanki proporcjonalności wymaga zbadania, czy norma wprowadzająca ograniczenie jest przydatna, czyli czy rzeczywiście doprowadzi do zamierzonych przez ustawodawcę skutków. Ponadto czy norma ta jest konieczna, czyli czy jest niezbędna dla ochrony interesu publicznego, z którym jest powiązana, oraz czy jest proporcjonalna sensu stricto, czyli czy efekty wprowadzonego ograniczenia pozostają w odpowiedniej proporcji do nałożonych przez normę na obywateli ciężarów i ograniczeń ${ }^{15}$. Zatem ingerencja $\mathrm{w}$ sferę statusu prawnego jednostki, mimo że jest uzasadniona, nie może być nadmierna, ponieważ doprowadziłoby to do naruszenia istoty prawa czy też wolności ograniczanej ${ }^{16}$.

Następny wymóg pozwalający na wprowadzenie dozwolonych ograniczeń praw i wolności człowieka, w tym również wolności religii, wynikający z art. 31 ust. 3 Konstytucji RP, to konieczność ustanowienia takiego ograniczenia w społeczeństwie demokratycznym. W doktrynie społeczeństwo demokratyczne jest określane jako takie, w którym występuje pluralizm religijny i światopoglądowy ${ }^{17}$. Trybunał Europejski w sprawie Eweida i inni v. Wielka Brytania ${ }^{18}$, podkreślił, że prawo do wolności religijnej gwarantowane $\mathrm{w}$ art. 9 Europejskiej Konwencji ${ }^{19}$, to prawo podstawowe, ponieważ zdrowe społeczeństwo demokratyczne powinno tolerować i chronić pluralizm i różnorodność religijną ${ }^{20}$. Każdy człowiek w takim społeczeństwie ma swobodę w zakresie rozwoju i korzystania z przysługujących mu praw, na straży których stoją kompetentne organy państwo$w^{21}$. Dlatego dla funkcjonowania społeczeństwa i państwa konieczne jest

14 Orzeczenie Trybunału Konstytucyjnego z dnia 23 listopada 2009 r., P 61/08, OTK-A 2009, Nr 10, poz. 150.

15 Karpiuk 2017, 12-13; Sroka 2020, 80-81; Olszówka, Dyda 2020, 448.

16 Ruczkowski 2012, 83.

17 Pietrzak 2013, 290; Piechowiak 2009, 57.

18 Wyrok ETPC z dnia 15 stycznia 2013 r., Eweida i inni v. Wielka Brytania, skargi nr 48420/10, 59842/10, 51671/10, 36516/10, LEX nr 1252935.

19 Konwencja o Ochronie Praw Człowieka i Podstawowych Wolności z dnia 4 listopada 1950 r., Dz. U. z 1993 r. Nr 61, poz. 284 z późn. zm.

20 Abramowicz 2015, 17.

21 Warchałowski 2004, 157. 
w pewnych sytuacjach wprowadzanie ograniczeń wolności człowieka po to, by z tych wolności mogli korzystać wszyscy ludzie ${ }^{22}$.

Należy zauważyć również, że Konstytucja RP w art. 233 stanowi, iż ustawa określająca zakres ograniczeń wolności i praw człowieka i obywatela w czasie stanu wojennego i wyjątkowego nie może limitować wolności religijnej. Podobnie w czasie stanu klęski żywiołowej można wprowadzić ograniczenia jedynie wymienionych w tym artykule wolności i praw człowieka i obywatela, a wśród nich Konstytucja RP nie wymienia wolności religijnej ${ }^{23}$. Wskazany przepis konstytucyjny nie pozostawia więc organom władz publicznych swobody w określaniu, jakie prawa i wolności mogą podlegać ograniczeniom. Odpowiada to standardom prawa międzynarodowego, tj. z art. 4 ust. 2 Międzynarodowego Paktu Praw Obywatelskich i Politycznych ${ }^{24}$ oraz z art. 15 ust. 2 Konwencji o Ochronie Praw Człowieka i Podstawowych Wolności ${ }^{25}$. Zatem wolność sumienia i religii w czasie stanów nadzwyczajnych nie może być ograniczana na innych zasadach niż ogólne wynikające z art. 31 ust. 3 i art. 53 ust. 5 Konstytucji RP ${ }^{26}$. Chociaż należy pamiętać, że w czasie trwania poszczególnych stanów nadzwyczajnych ustawodawca może ograniczyć również prawa i wolności konstytucyjne, które w istotny sposób wpływają na realizację uprawnień wynikających z wolności sumienia i religii ${ }^{27}$.

\section{OGRANICZENIA WOLNOŚCI UZEWNĘTRZNIANIA RELIGII} W CZASIE ROZPRZESTRZENIANIA SIĘ KORONAWIRUSA W POLSCE

Pierwszym wydanym aktem prawnym dotyczącym ograniczeń w zakresie korzystania z wolności religijnej w Polsce w okresie zagrożenia i rozprze-

22 Kazimierczuk 2014, 103-104.

23 Misztal 2011, 73; Stanisz 2017, 48.

24 Międzynarodowy Pakt Praw Obywatelskich i Politycznych, otwarty do podpisu w Nowym Jorku w dniu 19 grudnia 1966 r., Dz. U. z 1977 r. Nr 38, poz. 167.

25 Kazimierczuk 2018, 118-119.

26 Olszówka, Dyda 2020, 451.

27 Zob. szerzej Ożóg 2016, 48-67. 
strzeniania się koronawirusa była ustawa z dnia 2 marca 2020 r. ${ }^{28}$ Artykulem 25 tego aktu dokonano nowelizacji ustawy z dnia 5 grudnia 2008 r. $^{29}$ Następnie 13 marca 2020 r. zostało wydane rozporządzenie Ministra Zdrowia w sprawie ogłoszenia na obszarze Rzeczypospolitej Polskiej stanu zagrożenia epidemicznego ${ }^{30}$, które ustanowiło od dnia 14 marca $2020 \mathrm{r}$. czasowe ograniczenie sprawowania kultu religijnego w miejscach publicznych, w tym w budynkach i innych obiektach kultu religijnego. Ograniczenia te polegały na konieczności zapewnienia, aby w trakcie sprawowania kultu religijnego na danym terenie lub w danym obiekcie nie znajdowało się łącznie, zarówno wewnątrz, jak i na zewnątrz pomieszczeń, więcej niż 50 osób, wliczając w to uczestników i osoby sprawujące kult religijny. Wymienione ograniczenia zostały utrzymane kolejnym rozporządzeniem Ministra Zdrowia z dnia 20 marca 2020 r. ${ }^{31}$, które na obszarze całego państwa wprowadzało stan epidemii przy jednoczesnym zniesieniu stanu zagrożenia epidemicznego ${ }^{32}$. Następnie wymienione ograniczenia zostały zaostrzone rozporządzeniem z dnia 24 marca $2020 \mathrm{r}^{33}$ Mianowicie w okresie od 20 marca 2020 r. do 24 marca 2020 r. oraz w okresie od 12 kwietnia 2020 r. do odwołania, limit 50 osób w trakcie sprawowania kultu religijnego wprowadzono również w stosunku do osób zatrudnionych przez za-

28 Ustawa z dnia 2 marca 2020 r. o szczególnych rozwiązaniach związanych z zapobieganiem, przeciwdziałaniem i zwalczaniem COVID-19, innych chorób zakaźnych oraz wywołanych nimi sytuacji kryzysowych, tekst jedn. Dz. U. z 2020 r., poz. 1842 z późn. zm.

29 Ustawa z dnia 5 grudnia 2008 r. o zapobieganiu oraz zwalczaniu zakażeń i chorób zakaźnych u ludzi, tekst jedn. Dz. U. z 2020 r., poz. 1845 z późn. zm.

30 Rozporządzenie Ministra Zdrowia z dnia 13 marca 2020 r. w sprawie ogłoszenia na obszarze Rzeczypospolitej Polskiej stanu zagrożenia epidemicznego, Dz. U. z 2020 r., poz. 433.

31 Rozporządzenie Ministra Zdrowia z dnia 20 marca 2020 r. w sprawie ogłoszenia na obszarze Rzeczypospolitej Polskiej stanu epidemii, Dz. U. z 2020 r., poz. 491.

32 Rozporządzenie Ministra Zdrowia z dnia 20 marca 2020 r. w sprawie odwołania na obszarze Rzeczypospolitej Polskiej stanu zagrożenia epidemicznego, Dz. U. z 2020 r., poz. 490.

33 Rozporządzenie Ministra Zdrowia z dnia 24 marca 2020 r. zmieniające rozporządzenie w sprawie ogłoszenia na obszarze Rzeczypospolitej Polskiej stanu epidemii z dnia 20 marca 2020 r., Dz. U. z 2020 r., poz. 522. Wskazane ograniczenia sprawowania kultu religijnego zostały utrzymane przez rozporządzenie Rady Ministrów z dnia 31 marca 2020 r. w sprawie ustanowienia określonych ograniczeń, nakazów i zakazów w związku z wystąpieniem stanu epidemii, Dz. U. z 2020 r., poz. 566. 
kład pogrzebowy w przypadku pogrzebu. Następnie w okresie od 25 marca 2020 r. do 11 kwietnia 2020 r. limit 50 osób został zaostrzony do 5 osób, oprócz osób sprawujących kult religijny lub osób zatrudnionych przez zakład pogrzebowy w przypadku pogrzebu. Ponadto we wskazanym okresie zakazano organizowania innych zgromadzeń w ramach działalności kościołów i innych związków wyznaniowych. We wskazanym rozporządzeniu wprowadzono również zakaz przemieszczania się na terenie całego kraju. Ustanowiono jednakże od niego wyjątki, pośród których umieszczono możliwość przemieszczania się w celu sprawowania oraz uczestniczenia w sprawowaniu kultu religijnego oraz czynnościach lub obrzędach religijnych.

Wymienione ograniczenia zostały przedłużone do 19 kwietnia $2020 \mathrm{r}$. rozporządzeniem z dnia 10 kwietnia $2020 \mathrm{r}^{34}$ Natomiast od 20 kwietnia 2020 r. do odwołania wskazane rozporządzenie łagodziło ograniczenia sprawowania kultu religijnego w miejscach publicznych, w tym w budynkach i innych obiektach kultu religijnego. Wprowadzono obowiązek zapewnienia, aby w trakcie sprawowania kultu religijnego, w tym czynności lub obrzędów religijnych, na danym terenie lub w danym obiekcie znajdowało się łącznie, zarówno wewnątrz, jak i na zewnątrz pomieszczeń, nie więcej niż 50 osób, wliczając w to uczestników i osoby sprawujące kult religijny lub osoby dokonujące pochowania lub osoby zatrudnione przez zakład lub dom pogrzebowy w przypadku pogrzebu, a nie jak do tej pory 5 osób. Nadal natomiast utrzymano zakaz organizowania zgromadzeń w ramach działalności kościołów i innych związków wyznaniowych.

Należy zauważyć, że rozporządzenie z dnia 15 kwietnia 2020 r. ${ }^{35}$ wprowadziło nowe obostrzenie dotyczące uczestniczenia w sprawowaniu kultu religijnego. Mianowicie od 16 kwietnia 2020 r. do odwołania został nałożony obowiązek zakrywania, przy pomocy odzieży lub jej części, maski albo maseczki, ust i nosa w miejscach ogólnodostępnych, w tym w budynkach użyteczności publicznej przeznaczonych na potrzeby kultu religijnego.

34 Rozporządzenie Rady Ministrów z dnia 10 kwietnia 2020 r. w sprawie ustanowienia określonych ograniczeń, nakazów i zakazów w związku z wystąpieniem stanu epidemii, Dz. U. z 2020 r., poz. 658.

35 Rozporządzenie Rady Ministrów z dnia 15 kwietnia 2020 r. zmieniające rozporządzenie w sprawie ustanowienia określonych ograniczeń, nakazów i zakazów w związku z wystąpieniem stanu epidemii, Dz. U. z 2020 r., poz. 673. 
Z tego obowiązku zostali zwolnieni duchowni sprawujący kult religijny, w tym czynności lub obrzędy religijne, podczas jego sprawowania.

Kolejne rozporządzenie z dnia 19 kwietnia $2020 \mathrm{r}^{36}{ }^{36}$ utrzymało dotychczasowe ograniczenia, dokonało jednak zmiany zapowiadanego złagodzenia limitu 5 osób na 50 osób mogących uczestniczyć w czasie sprawowania kultu religijnego lub dokonywania pochowania przez osoby zatrudnione przez zakład lub dom pogrzebowy w przypadku pogrzebu. Mianowicie od 20 kwietnia 2020 r. w trakcie sprawowania kultu religijnego, w tym czynności lub obrzędów religijnych, w budynku użyteczności publicznej przeznaczonym na potrzeby kultu religijnego mógł znajdować się 1 uczestnik na $15 \mathrm{~m}^{2}$ powierzchni tego budynku, oprócz osób sprawujących kult religijny, a na cmentarzu mogło znajdować się nie więcej niż 50 uczestników podczas jednego pogrzebu, oprócz osób sprawujących kult religijny, osób dokonujących pochowania lub osób zatrudnionych przez zakład lub dom pogrzebowy. Zmiana ta została doszczegółowiona przez rozporządzenie $\mathrm{z}$ dnia 2 maja $2020 \mathrm{r}^{37}$ Mianowicie w trakcie sprawowania kultu religijnego, w tym czynności lub obrzędów religijnych, w budynku użyteczności publicznej przeznaczonym na potrzeby kultu religijnego powinien znajdować się 1 uczestnik na $15 \mathrm{~m}^{2}$ powierzchni tego budynku, oprócz osób sprawujących kult religijny, z wyjątkiem takiego budynku o powierzchni mniejszej niż $75 \mathrm{~m}^{2}$, w którym dopuszcza się jednoczesne przebywanie 5 uczestników, oprócz osób sprawujących kult religijny przy utrzymaniu pozostałych ograniczeń. Wskazana zmiana została utrzymana do dnia wydania rozporządzenia z dnia 16 maja $2020 \mathrm{r}^{38}$, które od dnia następnego zezwalało, aby w trakcie sprawowania kultu religijnego, w tym czynności lub obrzędów religijnych, w budynku użyteczności publicznej przeznaczonym na potrzeby kultu religijnego znajdował

36 Rozporządzenie Rady Ministrów z dnia 19 kwietnia 2020 r. w sprawie ustanowienia określonych ograniczeń, nakazów i zakazów w związku z wystąpieniem stanu epidemii, Dz. U. z 2020 r., poz. 697.

37 Rozporządzenie Rady Ministrów z dnia 2 maja 2020 r. w sprawie ustanowienia określonych ograniczeń, nakazów i zakazów w związku z wystąpieniem stanu epidemii, Dz. U. z 2020 r., poz. 792.

38 Rozporządzenie Rady Ministrów z dnia 16 maja 2020 r. w sprawie ustanowienia określonych ograniczeń, nakazów i zakazów w związku z wystąpieniem stanu epidemii, Dz. U. z 2020 r., poz. 878. 
się 1 uczestnik na $10 \mathrm{~m}^{2}$ powierzchni tego budynku, oprócz osób sprawujących kult religijny, z wyjątkiem budynku o powierzchni mniejszej niż $50 \mathrm{~m}^{2}$, w którym dopuszcza się jednoczesne przebywanie 5 uczestników, oprócz osób sprawujących kult religijny. Wcześniej wprowadzone ograniczenia zostały utrzymane.

Istotną zmianę dotyczącą możliwości sprawowania i uczestniczenia w kulcie religijnym wprowadziło rozporządzenie z dnia 29 maja $2020 \mathrm{r}^{39}$ Dotychczasowe ograniczenia zostały zmienione postanowieniem zezwalającym na organizowanie od 30 maja 2020 r. zgromadzeń w ramach działalności kościołów i innych związków wyznaniowych, pod warunkiem że w przypadku gdy zgromadzenie odbywa się w budynkach i innych obiektach kultu religijnego uczestnicy zakrywają, przy pomocy odzieży lub jej części, maski, maseczki, przyłbicy albo kasku ochronnego usta i nos, z wyłączeniem osób sprawujących kult religijny, a w przypadku gdy to zgromadzenie odbywa się na zewnątrz, uczestnicy przebywają w odległości nie mniejszej niż 2 m od siebie lub zakrywają we właściwy sposób usta i nos, z wyłączeniem osób sprawujących kult religijny. Wskazana zmiana została utrzymana i potwierdzona rozporządzeniem z dnia 19 czerwca $2020 \mathrm{r}^{40}$

Rozporządzenie z dnia 7 sierpnia $2020 \mathrm{r}^{41}$ wprowadziło dodatkowe ograniczenia dotyczące zgromadzeń organizowanych w ramach działalności kościołów i innych związków wyznaniowych, które mogły się odbywać w obszarze czerwonym w budynkach i innych obiektach kultu religijnego, gdzie jednocześnie mogło znajdować się nie więcej uczestników niż wynosi 50\% obłożenia budynku lub innego obiektu kultu religijnego, oprócz osób sprawujących kult religijny lub osób dokonujących pochowania, lub osób zatrudnionych przez zakład lub dom pogrzebowy w przypadku pogrzebu. Jednocześnie został utrzymany w stosunku do uczestników

39 Rozporządzenie Rady Ministrów z dnia 29 maja 2020 r. w sprawie ustanowienia określonych ograniczeń, nakazów i zakazów w związku z wystąpieniem stanu epidemii, Dz. U. z 2020 r., poz. 964.

40 Rozporządzenie Rady Ministrów z dnia 19 czerwca 2020 r. w sprawie ustanowienia określonych ograniczeń, nakazów i zakazów w związku z wystąpieniem stanu epidemii, Dz. U. z 2020 r., poz. 1066.

41 Rozporządzenie Rady Ministrów z dnia 7 sierpnia 2020 r. w sprawie ustanowienia określonych ograniczeń, nakazów i zakazów w związku z wystąpieniem stanu epidemii, Dz. U. z 2020 r., poz. 1356. 
obowiązek zakrywania ust i nosa, z wyłączeniem osób sprawujących kult religijny. Nakaz ten obowiązywał również na zewnątrz bez względu na odległość między osobami z wyłączeniem osób sprawujących kult religijny.

Kolejne rozporządzenie z dnia 9 października $2020 \mathrm{r}^{42}$ wprowadziło zmianę dotyczącą zgromadzeń organizowanych w ramach działalności kościołów i innych związków wyznaniowych. Zezwoliło na ich organizowanie pod warunkiem, że w budynkach i innych obiektach kultu religijnego znajduje się (przy zachowaniu odległości nie mniejszej niż 1,5 m) nie więcej uczestników niż 1 osoba na $15 \mathrm{~m}^{2}$ powierzchni - do 29 listopada 2020 r. oraz 1 osoba na $7 \mathrm{~m}^{2}$ powierzchni - od 30 listopada $2020 \mathrm{r}$. - oprócz osób sprawujących kult religijny lub osób dokonujących pochowania, lub osób zatrudnionych przez zakład lub dom pogrzebowy w przypadku pogrzebu, oraz że uczestnicy realizują obowiązek zakrywania ust i nosa, z wyłączeniem osób sprawujących kult religijny. Natomiast na zewnątrz uczestnicy przebywają w odległości nie mniejszej niż 1,5 m od siebie i realizują obowiązek zakrywania ust i nosa, z wyłączeniem osób sprawujących kult religijny.

Rozporządzenie z dnia 16 października $2020 \mathrm{r}^{43}$ natomiast określiło, że zgromadzenia organizowane w ramach działalności kościołów i innych związków wyznaniowych mogą się odbywać, pod warunkiem że w przypadku gdy zgromadzenie odbywa się w budynkach i innych obiektach kultu religijnego, znajduje się w nich, przy zachowaniu odległości nie mniejszej niż $1,5 \mathrm{~m}$, nie więcej uczestników niż 1 osoba na $4 \mathrm{~m}^{2}$ powierzchni $\mathrm{w}$ obszarze żółtym albo 1 osoba na $7 \mathrm{~m}^{2}$ powierzchni w obszarze czerwonym, oprócz osób sprawujących kult religijny lub osób dokonujących pochowania, lub osób zatrudnionych przez zakład lub dom pogrzebowy w przypadku pogrzebu, oraz że uczestnicy realizują obowiązek zakrywania ust i nosa, z wyłączeniem osób sprawujących kult religijny. Na zewnątrz natomiast uczestnicy powinni przebywać w odległości nie mniejszej niż 1,5 m od siebie i realizować obowiązek zakrywania ust i nosa, z wyłączeniem

42 Rozporządzenie Rady Ministrów z dnia 9 października 2020 r. w sprawie ustanowienia określonych ograniczeń, nakazów i zakazów w związku z wystąpieniem stanu epidemii, Dz. U. z 2020 r., poz. 1758.

43 Rozporządzenie Rady Ministrów z dnia 16 października 2020 r. zmieniające rozporządzenie w sprawie ustanowienia określonych ograniczeń, nakazów i zakazów w związku z wystąpieniem stanu epidemii, Dz. U. z 2020 r., poz. 1829. 
osób sprawujących kult religijny. Rozporządzenie z dnia 23 października $2020 \mathrm{r}^{44}$ rozciągnęło z kolei limit 1 osoby na $7 \mathrm{~m}^{2}$ powierzchni w czasie zgromadzeń organizowanych w ramach działalności kościołów i innych związków wyznaniowych na obszar całego kraju.

Dalej idące ograniczenia zostały wprowadzone przez rozporządzenie z dnia 26 listopada 2020 r. ${ }^{45}$ Do 27 grudnia 2020 r. zgromadzenia organizowane w ramach działalności kościołów i innych związków wyznaniowych mogły się odbywać pod warunkiem, że w przypadku gdy zgromadzenie odbywa się w budynkach i innych obiektach kultu religijnego znajduje się w nich, przy zachowaniu odległości nie mniejszej niż $1,5 \mathrm{~m}$, nie więcej uczestników niż 1 osoba na $15 \mathrm{~m}^{2}$ powierzchni, oprócz osób sprawujących kult religijny lub osób dokonujących pochowania, lub osób zatrudnionych przez zakład lub dom pogrzebowy w przypadku pogrzebu oraz że uczestnicy realizują obowiązek zakrywania ust i nosa, z wyłączeniem osób sprawujących kult religijny. Na zewnątrz zaś uczestnicy powinni przebywać w odległości nie mniejszej niż 1,5 m od siebie i realizować obowiązek zakrywania ust i nosa, z wyłączeniem osób sprawujących kult religijny. Ponadto przed wejściem do budynków i innych obiektów kultu religijnego przepisy rozporządzenia nakazywały umieścić informację o limicie osób mogących znajdować się w środku oraz podjąć środki zapewniające jego przestrzeganie.

W kolejnych miesiącach zostały wydane następne rozporządzenia, w których dokonywano zmian wskazanych wcześniej ograniczeń dotyczących sprawowania kultu religijnego. Należy zauważyć jednak, że 28 października 2020 r. Sejm uchwalił ustawę o zmianie niektórych ustaw w związku z przeciwdziałaniem sytuacjom kryzysowym związanym z wystąpieniem COVID-1946, w której w art. 15 pkt 2 lit. c wpro-

44 Rozporządzenie Rady Ministrów z dnia 23 października 2020 r. zmieniające rozporządzenie w sprawie ustanowienia określonych ograniczeń, nakazów i zakazów w związku z wystąpieniem stanu epidemii, Dz. U. z 2020 r., poz. 1871.

45 Rozporządzenie Rady Ministrów z dnia 26 listopada 2020 r. w sprawie ustanowienia określonych ograniczeń, nakazów i zakazów w związku z wystąpieniem stanu epidemii, Dz. U. 2020 r., poz. 2091.

46 Ustawa z dnia 28 października 2020 r. o zmianie niektórych ustaw w związku z przeciwdziałaniem sytuacjom kryzysowym związanym z wystąpieniem COVID-19, Dz. U. z 2020 r., poz. 2112. 
wadzona została zmiana dotycząca art. 46b wspomnianej wyżej ustawy z dnia 5 grudnia 2008 r. o zapobieganiu oraz zwalczaniu zakażeń i chorób zakaźnych u ludzi, polegająca na dodaniu do art. 46b punktu 13, na mocy którego na poziomie ustawowym został unormowany „nakaz zakrywania ust i nosa, w określonych okolicznościach, miejscach i obiektach oraz na określonych obszarach, wraz ze sposobem realizacji tego nakazu". Zatem wskazany nakaz znajduje swoją podstawę prawną w ustawie, a nie jak do tej pory w rozporządzeniu.

Obecnie ograniczenia dotyczące sprawowania kultu religijnego obowiązują na mocy rozporządzenia $\mathrm{z}$ dnia 6 maja $2021 \mathrm{r}^{47}$ Zgodnie $\mathrm{z}$ tym aktem do 5 czerwca 2021 r. zgromadzenia organizowane w ramach działalności kościołów i innych związków wyznaniowych mogą się odbywać pod warunkiem, że w przypadku gdy zgromadzenie odbywa się w budynkach i innych obiektach kultu religijnego, znajduje się w nich, przy zachowaniu odległości nie mniejszej niż 1,5 m, nie więcej uczestników niż 1 osoba na $15 \mathrm{~m}^{2}$ powierzchni, oprócz osób sprawujących kult religijny lub osób dokonujących pochowania, lub osób zatrudnionych przez zakład lub dom pogrzebowy w przypadku pogrzebu oraz że uczestnicy realizują obowiązek zakrywania ust i nosa, z wyłączeniem osób sprawujących kult religijny. Na zewnątrz zaś uczestnicy mogą przebywać w odległości nie mniejszej niż 1,5 m od siebie. Ponadto przed wejściem do budynków i innych obiektów kultu religijnego przepisy rozporządzenia nakazują umieścić informację o limicie osób mogących znajdować się w środku oraz podjąć środki zapewniające jego przestrzeganie.

\section{OCENA ZGODNOŚCI Z KONSTYTUCJĄ OGRANICZEŃ WOLNOŚCI UZEWNĘTRZNIANIA RELIGII}

Należy zauważyć, że obowiązkiem państwa jest zabezpieczenie przysługujących każdemu człowiekowi praw i wolności oraz zapewnienie bezpieczeństwa obywateli w każdej sferze życia. Realizacja tego obowiązku

47 Rozporządzenie Rady Ministrów z dnia 6 maja 2021 r. w sprawie ustanowienia określonych ograniczeń, nakazów i zakazów w związku z wystąpieniem stanu epidemii, Dz. U. z 2021 r., poz. 861. 
z perspektywy art. 1 Konstytucji RP: „Rzeczpospolita Polska jest dobrem wspólnym wszystkich obywateli" jest przejawem troski państwa o dobro wspólne. W tym zakresie mieszczą się działania podejmowane przez państwo dla ochrony życia i zdrowia człowieka. Potwierdzają to normy konstytucyjne w art. 38: „Rzeczpospolita Polska zapewnia każdemu człowiekowi prawną ochronę życia” oraz art. 68 ust. 1: „Każdy ma prawo do ochrony zdrowia” i ust. 4: „Władze publiczne są zobowiązane do zwalczania chorób epidemicznych i zapobiegania negatywnym dla zdrowia skutkom degradacji środowiska". Zatem państwo nie jest dysponentem życia ludzkiego, jednak poprzez właściwe działania powinno zapewnić jego prawną ochronę ${ }^{48}$. Dlatego art. 38 i art. 68 Konstytucji RP gwarantują każdemu człowiekowi ochronę życia i zdrowia oraz zobowiązują władze publiczne do zwalczania chorób epidemicznych. Działania takie mogą polegać na wprowadzeniu ograniczeń praw i wolności człowieka w celu wyeliminowania zachowań ryzykownych ${ }^{49}$. Adresatem normy art. 68 ust. 4 Konstytucji RP są wszystkie władze publiczne, natomiast beneficjentem jest ogół społeczeństwa, które powinno być chronione przed chorobami epidemicznymi. W tym celu władze publiczne powinny podejmować działania nie tylko o charakterze represyjnym, ale również prewencyjnym, których celem jest zapobieganie powstawaniu i rozprzestrzenianiu się chorób epidemicznych ${ }^{50}$. Należy pamiętać, że państwo jest zobowiązane do ochrony wszystkich przysługujących człowiekowi praw i wolności nawet w czasie zagrożenia epidemicznego. Jednak takie zagrożenie może spowodować konieczność wprowadzenia zgodnie z normami konstytucyjnymi ograniczeń przysługujących praw i wolności człowieka ${ }^{51}$.

Wymienione wyżej ograniczenia dotyczące możliwości uczestniczenia i sprawowania kultu religijnego budzą wątpliwości co do ich legalności i konstytucyjności. Takie zarzuty zostały sformułowane $\mathrm{w}$ piśmie Rzecznika Praw Obywatelskich kierowanym do Prezesa Rady Ministrów z dnia 27 marca 2020 r. $^{52}$, w którym negatywnie odniósł się on do

48 Lis 2017, 32-33.

49 Sroka 2020, 76-77.

50 Miaskowska-Daszkiewicz 2017, 69-71.

51 Sroka 2020, 78.

52 https:/www.rpo.gov.pl/sites/default/files/Rozporz\%C4\%85dzenia\%20MZ\%20COVID-19\%2027.03.2020.pdf [dostęp: 30.05.2021]. 
właściwości trybu wprowadzonych ograniczeń. Podkreślił, że „żaden organ władzy wykonawczej, w tym minister właściwy do spraw zdrowia, nie posiada w świetle art. 53 ust. 5 Konstytucji RP zdolności regulacyjnej w zakresie określania granic wolności uzewnętrzniania religii”. Stanowisko to Rzecznik Praw Obywatelskich powtórzył i rozbudował w kolejnych pismach do Prezesa Rady Ministrów ${ }^{53}$. Podkreślił w nich, że ograniczenia praw i wolności człowieka muszą być wprowadzone z poszanowaniem konstytucyjnych standardów ich ochrony. Ponadto wskazał, że ustrojodawca nadał wolności religii szczególną rangę, jako jednemu z podstawowych praw człowieka. Podkreślił również, że ograniczenia wolności uzewnętrzniania religii nie mogą mieć formy zakazu, ponieważ stanowi to ograniczenie istoty wolności gwarantowanej w art. 53 Konstytucji RP i jest niedopuszczalne według art. 31 ust. 3 Konstytucji RP. W konsekwencji rekomendował, aby ograniczenia podstawowych praw i wolności, w tym wolności uzewnętrzniania religii, były regulowane w ustawie, ponieważ to ,zapewni poszanowanie standardów wynikających z Konstytucji RP i uniemożliwi organom władzy wykonawczej nadużywanie przysługujących im kompetencji”.

Niewątpliwie wprowadzane przez państwo ograniczenia wolności uzewnętrzniania religii motywowane są dążeniem do wyeliminowania zagrożenia spowodowanego rozprzestrzenianiem się koronawirusa. Zatem spełniają przesłankę ochrony zdrowia określoną w przepisach konstytucyjnych. Wprowadzone ograniczenia powinny również realizować przesłankę formalną w postaci wymogu ustawowej formy wprowadzenia ograniczeń wolności religii. Wymienione wyżej ograniczenia zostały wprowadzone na mocy rozporządzeń Ministra Zdrowia wydanych na podstawie upoważnienia zawartego w art. 46 ust. 2 i 4 powołanej wyżej ustawy z dnia 5 grudnia 2008 r. o zapobieganiu oraz zwalczaniu zakażeń i chorób zakaźnych u ludzi oraz rozporządzeń Rady Ministrów na podstawie upoważnienia zawartego w tej samej ustawie w art. 46a i art. 46b pkt 1-6 i 8-12, a nie jak

53 Pismo z dnia 3 kwietnia 2020 r. do Prezesa Rady Ministrów, https://www.rpo.gov.pl/ sites/default/files/Pismo\%20do\%20Prezesa\%20Rady\%20Ministr\%C3\%B3w.\%203.04.2020. pdf [dostęp: 30.05.2021]; Pismo z dnia 4 czerwca 2020 do Prezesa Rady Ministrów, https:// www.rpo.gov.pl/sites/default/files/do $\% 20$ Prezesa $\% 20 \mathrm{RM} \% 20 \mathrm{ws} \% 20$ naruszania $\% 20$ praw $\% 20$ i\%20wolno $\%$ C5\%9Bci $\% 20$ w $\% 20$ czasie $\% 20$ pandemii $\% 2$ C $\% 20$ 4.06.2020_0.pdf [dostęp: 30.05.2021]. 
tego wymaga przepis konstytucyjny w ustawie. Badając treść wskazanych przepisów zawierających upoważnienia ustawowe do wydania właściwych rozporządzeń w zakresie przeciwdziałania niebezpieczeństwom w czasie stanu zagrożenia epidemicznego lub stanu epidemii należy zauważyć brak upoważnienia do wprowadzenia ograniczeń dotyczących sprawowania kultu religijnego. Wskazane delegacje ustawowe w swojej treści nie przewidują takiej możliwości ${ }^{54}$. Należy zatem zgodzić się ze stanowiskiem Rzecznika Praw Obywatelskich, że w tym zakresie organy władzy wykonawczej nie mają upoważnienia do regulowania ograniczeń wolności uzewnętrzniania religii. Ta materia powinna być regulowana w ustawie ${ }^{55}$. Przedstawione rozważania pozwalają zatem na stwierdzenie, że wymieniona konstytucyjna przesłanka konieczna do wprowadzenia dozwolonych ograniczeń wolności religii nie została spełniona przy wprowadzaniu ograniczeń dotyczących możliwości uczestniczenia i sprawowania kultu religijnego w czasie zagrożenia wywołanego rozprzestrzenianiem się koronawirusa.

Wprowadzane ograniczenia wolności człowieka powinny spełniać również wymagania zasady proporcjonalności. Ocena właściwej proporcjonalności wprowadzonych rozwiązań powinna opierać się na aktualnym stanie rozwoju epidemii, co pozwoliłoby na ocenę konieczności wprowadzonych ograniczeń dla ochrony zdrowia ludzkiego ${ }^{56}$. Należy stwierdzić, że w świetle rekomendacji ekspertów epidemiologii wprowadzenie

54 Olszówka, Dyda 2020, 446, 453; Stańczuk 2020, 484; Abramowicz 2020, 23.

55 Stanisz 2021, 152-157.

56 J. Kwaśniewski, T. Zych, M. Olszówka, K. Dyda, Analiza wprowadzonych $w$ związu z przeciwdziataniem epidemii koronawirusa ograniczeń wolności religii $i$ swobody przemieszczania się $w$ świetle standardów Konstytucji RP i prawa międzynarodowego, 16 kwietnia 2020 r., https://ordoiuris.pl/wolnosci-obywatelskie/analiza-wprowadzonych-w-zwiazku-z-przeciwdzialaniem-epidemii-koronawirusa [dostęp: 30.05.2021]; M. Olszówka, K. Dyda, Analiza zgodności z Konstytucja RP ograniczeń w korzystaniu $z$ wolności religii $i$ przemieszczania się zwiazanych $z$ pandemia koronawirusa SARS-Cov-2 oraz strategii ich znoszenia (stan na 14 maja 2020 r.), https://ordoiuris.pl/wolnosci-obywatelskie/analiza-zgodnosci-z-konstytucja-rp-ograniczen-w-korzystaniu-z-wolnosci [dostęp: 30.05.2021]; B. Zalewski, Opinia prawna dotycząca ograniczeń w sprawowaniu $k u l t u$ religijnego $w$ zwiazku ze stanem epidemii (stan prawny na 12 listopada 2020 r.), https://ordoiuris.pl/opinia-prawna-dotyczaca-ograniczen-w-sprawowaniu-kultu-religijnego-w-zwiazku-ze-stanem-epidemii [dostęp: 30.05.2021]. 
ograniczeń ilościowych osób w czasie sprawowania kultu religijnego jest uzasadnione ${ }^{57}$. Zostało to również przyjęte ze zrozumieniem przedstawicieli poszczególnych związków wyznaniowych w Polsce, którzy w zakresie swojej władzy wprowadzali rozwiązania mające na celu zmniejszenie ryzyka zakażenia w czasie publicznego sprawowania kultu religijnego. Za takie należy uznać czasowe wprowadzenie dyspensy od obowiązku uczestnictwa we mszy św. niedzielnej i w święta nakazane wprowadzonej we wszystkich diecezjach Kościoła Katolickiego, co było rekomendowane przez Prezydium Konferencji Episkopatu Polski. Podobnie w Kościele Ewangelicko-Augsburskim czasowo zawieszono celebrację wszystkich nabożeństw i spotkań parafialnych. Natomiast Muzułmański Związek Religijny w RP polecał wiernym praktykowanie modlitw w domach, ograniczając ich sprawowanie w świątyniach ${ }^{58}$.

Trzeba jednak podkreślić, że wprowadzanie poszczególnych już limitów powinno być poprzedzone właściwym uzasadnieniem. Za odpowiedni kierunek w zakresie wprowadzania ograniczeń ilościowych należy uznać określenie dozwolonego limitu obecnych osób w czasie sprawowania kultu w świątyni przypadających na określoną powierzchnię. Limit taki jednak powinien być również uzasadniony w oparciu o aktualną sytuację epidemiologiczną w kraju. Postulaty dotyczące „,bardziej spójnego, proporcjonalnego i sprawiedliwego kryterium ograniczania dopuszczalnej liczby wiernych w kościołach, podobnie jak to ma miejsce w przypadku innych podmiotów" zostały sformułowane przez Przewodniczącego Konferencji Episkopatu Polski ${ }^{59}$. Ponadto we wspólnym stanowisku przedstawiciele Kościoła Katolickiego, Kościołów zrzeszonych w Polskiej Radzie Ekumenicznej oraz Muzułmańskiego Związku Religijnego ${ }^{60}$ wyrazili swoje wątpliwości co do określonych limitów osób mogących uczestniczyć w kulcie

57 Olszówka, Dyda 2020, 456; zob. też Krzewicki 2020, 89.

58 Olszówka, Dyda 2020, 463-464.

59 List Przewodniczącego Episkopatu do Premiera RP ws. zmiany w ustalaniu liczby wiernych w kościele (15 kwietnia 2020), https://www.ekai.pl/dokumenty/list-przewodniczacego-episkopatu-do-premiera-rp-ws-zmiany-w-ustalaniu-liczby-wiernych-w-kosciele-15-kwietnia-2020/ [dostęp: 30.05.2021].

60 Przedstawiciele Kościołów i muzutmanie prosza premiera o większy limit osób w miejscach kultu, 30 kwietnia 2020 r., https://episkopat.pl/przedstawiciele-kosciolow-i-muzulmanie-prosza-premiera-o-wiekszy-limit-osob-w-miejscach-kultu/ [dostęp: 30.05.2020]. 
religijnym ${ }^{61}$. Podobne postulaty wysunęli biskupi francuscy, aby limit osób obecnych w czasie sprawowania kultu był określany w oparciu o kryterium wielkości kościoła ${ }^{62}$. Wprowadzanie takich rozwiązań należy uznać za przejaw dążenia do zastosowania środka najmniej restrykcyjnego. Władze państwowe nie powinny traktować miejsc kultu bardziej restrykcyjnie niż innych miejsc publicznych, zwłaszcza że prawo do realizacji wolności religijnej jest jednym z podstawowych praw człowieka ${ }^{63}$. Należy jednak pozytywnie ocenić fakt, że w Polsce mimo widocznych wątpliwości co do proporcjonalności wprowadzanych ograniczeń wolności kultu, nie wprowadzono całkowitego zakazu realizacji prawa do bezpośredniego uczestniczenia w kulcie religijnym. Taki zaś zakaz był wprowadzony we Włoszech i spotkał się z negatywną oceną ze strony Konferencji Episkopatu Włoch ${ }^{64}$.

Widoczny jest ponadto pogląd, że w świetle art. 25 ust. 3 Konstytucji RP, który wprowadza zasadę autonomii i niezależności państwa i związków wyznaniowych każdego w swoim zakresie, to generalnie władze związków wyznaniowych są uprawnione do określania zasad sprawowania kultu religijnego oraz ich zmian. Zatem ograniczenia dotyczące sprawowania kultu religijnego powinny być wprowadzane po uprzednim dokonaniu uzgodnienia pomiędzy władzami publicznymi i związkami wyznaniowymi z uwzględnieniem również obowiązku współdziałania dla dobra człowieka i dobra wspólnego ${ }^{65}$. Takie uzgodnienia są konieczne do zabezpieczenia właściwej realizacji wymogów doktrynalnych poszczególnych związków wyznaniowych w zakresie realizacji kultu i praktyk religijnych, tak aby wyeliminować trudności we właściwym unormowaniu ograniczeń wolności religii. Przykładem takiej sytuacji jest obowiązek

${ }^{61}$ Stanisz 2021, 151.

62 Kościół katolicki we Francji utracił sporo dochodów. „Finansowy szok”, 9 grudnia 2020 r., https://wiadomosci.onet.pl/swiat/koronawirus-francja-kosciol-katolicki-utracil-sporo-dochodow/gw0hvwt 12.12.2020 r. [dostęp: 30.05.2021].

${ }_{63}$ Zob. Maroń 2020, 123-151.

64 Stanisz 2021, 151. Zob. DPCM, la posizione della CEI, 26 Aprile 2020, https:// www.chiesacattolica.it/dpcm-la-posizione-della-cei/ [dostęp 30.05.2021].

65 Zob. powołane wyżej opracowania: J. Kwaśniewski, T. Zych, M. Olszówka, K. Dyda, Analiza wprowadzonych; M. Olszówka, K. Dyda, Analiza zgodności z Konstytucja RP; B. Zalewski, Opinia prawna dotyczaca ograniczeń; Olszówka, Dyda 2020, 462-463. Zob. też Krzewicki 2020, 83-100. 
zakrywania ust i nosa, z którego zwolniona jest osoba sprawująca kult religijny - duchowny w trakcie jego sprawowania. Takiego zwolnienia przepisy nie przewidują w żadnej innej sytuacji odnośnie do realizacji wymogów doktrynalnych poszczególnych związków wyznaniowych. Brak takich gwarancji widoczny jest chociażby w sytuacji przyjmowania sakramentu komunii świętej, kiedy niezbędne jest odsłonięcie ust. Trudno oczekiwać od strony państwowej znajomości unormowań wewnętrznych związków wyznaniowych w zakresie wymagań dotyczących form praktyk i kultu religijnego. Tym bardziej uzasadnia to konieczność dokonywania wspólnych uzgodnień w zakresie wprowadzania ograniczeń wolności uzewnętrzniania religii.

Trzeba podkreślić również, że widoczne są w doktrynie opinie, do których należy odnieść się z aprobatą, iż regulacje prawne określające procedury postępowania na wypadek epidemii wywołują trudności w zakresie skuteczności ich zastosowania i przeciwdziałania temu zagrożeniu oraz w zakresie proporcjonalności ingerencji w sferę praw i wolności człowieka $^{66}$. Trzeba przypomnieć, że art. 233 Konstytucji RP nie przewiduje możliwości ograniczenia wolności religijnej w czasie któregokolwiek ze stanów nadzwyczajnych, ponieważ pośród taksatywnie wskazanych praw i wolności człowieka, które mogą lub nie mogą być ograniczane, nie przewiduje takiej możliwości w stosunku do wolności religijnej. Dlatego sugerowane przez Rzecznika Praw Obywatelskich w przywołanym wyżej piśmie z dnia 27 marca 2020 r. rozwiązanie polegające na wprowadzeniu stanu klęski żywiołowej, który byłby właściwy dla zagrożenia wywołanego chorobą zakaźną, jest niewystarczające. Podobnie w czasie wprowadzenia stanu zagrożenia epidemicznego albo stanu epidemii dopuszczalne są jedynie takie ograniczenia wskazanej wolności, które można wprowadzić w czasie normalnego funkcjonowania państwa, czyli takie, które muszą spełniać przesłanki przewidziane w art. 53 ust. 5 i art. 31 ust. 3 Konstytucji RP. Zatem, jak zauważono w doktrynie, wprowadzenie stanu klęski żywiołowej nie pozwala na skuteczne zwalczanie epidemii w zakresie możliwości wprowadzenia ograniczeń wolności religijnej. Widoczny jest w tym zakresie również postulat konieczności zmiany właściwych przepisów konstytucyjnych, tak aby w sposób efektywny pozwalały na zwalczanie

66 Sroka 2020, 83-84. 
zagrożenia epidemicznego i gwarantowały hierarchiczną zgodność norm, ponieważ obowiązujące przepisy nie przewidują możliwości ograniczenia wolności uzewnętrzniania religii nawet w sytuacji zagrożenia wywołanego chorobą zakaźną ${ }^{67}$.

\section{PODSUMOWANIE}

Prawo do uczestniczenia w sprawowaniu kultu religijnego mieści się w zakresie wolności uzewnętrzniania religii. Polski prawodawca w sposób wyczerpujący określił zasady dotyczące możliwości wprowadzenia dozwolonych ograniczeń tej wolności w art. 53 ust. 5 Konstytucji RP. Ustanowione zostały tam przesłanki materialne: bezpieczeństwo państwa, porządek publiczny, zdrowie, moralność oraz wolności i prawa innych osób, a także przesłanka formalna w postaci wymogu ustawowej formy wprowadzenia ograniczeń wolności religii. Wymóg sprostania tej przesłance formalnej wynika również z art. 31 ust. 3 Konstytucji RP, który stanowi generalne wymogi dotyczące możliwości wprowadzania ograniczeń podstawowych praw i wolności człowieka. Przedstawione rozważania nie pozwalają na postawienie tezy, że wymieniona konstytucyjna przesłanka konieczna do wprowadzenia dozwolonych ograniczeń wolności religii została spełniona przy wprowadzaniu ograniczeń dotyczących możliwości uczestniczenia i sprawowania kultu religijnego w czasie zagrożenia rozprzestrzenianiem się koronawirusa.

Niewątpliwie zaistniała sytuacja zagrożenia z powodu rozprzestrzeniania się koronawirusa uzasadnia podejmowanie działań ze strony właściwych organów władzy państwowej w celu zapewnienia bezpieczeństwa i wyeliminowania zagrożenia dla zdrowia i życia poszczególnych osób. Jednak organy władzy publicznej powinny działać na podstawie i w granicach prawa. Przepisy konstytucyjne nie pozostawiają dowolności w zakresie możliwości wprowadzania ograniczeń praw i wolności człowieka, w tym również prawa do wolności religii. Ograniczenia takie zgodnie z przepisami konstytucyjnymi mogą być wprowadzone tylko w ustawie i tylko w sytuacji, gdy są konieczne w społeczeństwie demokratycznym

67 Stanisz 2021, 157-161. 
z powodu ochrony dóbr szczególnie chronionych. Muszą być proporcjonalne, aby nie naruszać samej istoty ograniczanego prawa. Trudno nie zauważyć również pojawiających się w doktrynie stanowisk, które zwracają uwagę na trudności w zakresie skuteczności zastosowania obecnych przepisów. Powinny one pozwolić właściwym organom władzy państwowej na podejmowanie skutecznych działań w celu wyeliminowania zagrożenia wywołanego chorobą zakaźną.

Zagadnienie dotyczące wprowadzanych z powodu pandemii koronawirusa ograniczeń wolności religii jest zagadnieniem złożonym i wielowątkowym. Budzi ono ożywioną dyskusję społeczną i prawną. Wymaga głębszego pochylenia się nad wynikającymi problemami prawnymi oraz podjęcia w tym zakresie dalszych badań naukowych. Pozwoli to na właściwą ocenę i dojrzałe wnioski dotyczące zgodności z prawem wprowadzonych ograniczeń wolności religijnej w czasie zagrożenia rozprzestrzenianiem się koronawirusa.

\section{BIBLIOGRAFIA}

Abramowicz, Aneta M. 2015. „Uzewnętrznianie symboli religijnych w miejscu pracy w świetle orzeczenia Europejskiego Trybunału Praw Człowieka z dnia 15 stycznia 2013 r. w sprawie Eweida i inni v. Zjednoczone Królestwo". W: Aktualne problemy wolności myśli, sumienia i religii, red. Piotr Stanisz, Aneta M. Abramowicz, Michał Czelny, Marta Ordon, Michał Zawiślak, 11-19. Lublin: Wydawnictwo KUL.

Abramowicz, Aneta M. 2020. „Limitations of the freedom to manifest religion in Poland during the spread of the coronavirus". Forum Iuris Europaeum 2: $15-25$.

Karpiuk, Mirosław. 2017. „Ograniczenie wolności uzewnętrzniania wyznania ze względu na bezpieczeństwo państwa i porządek publiczny”. Przegląd Prawa Wyznaniowego 9: 5-20.

Kazimierczuk, Marcin. 2014. „Pojęcie, istota oraz źródło wolności i praw człowieka". Studia Prawnoustrojowe 26: 101-114.

Kazimierczuk, Marcin. 2018. „Ograniczenie wolności i praw człowieka podczas stanu wyjątkowego w polskim prawodawstwie". Polski Rocznik Praw Człowieka i Prawa Humanitarnego 9: 111-124. 
Krzewicki, Jarosław. 2020. „Relacje Państwo-Kościół w Polsce wobec COVID-19”. Kościól i Prawo 1: 83-100.

Lis, Wojciech. 2017. „Działania podejmowane w przypadkach zakażeń i chorób zakaźnych ze względu na ochronę bezpieczeństwa obywateli”. Studia Prawnicze KUL 3: 31-50.

Maroń, Grzegorz. 2020. „Ograniczanie wolności religijnej w pierwszym okresie pandemii covid-19 w świetle orzecznictwa amerykańskich sądów”. Studia z Prawa Wyznaniowego 23: 123-151.

McCrea, Ronan. 2010. Religion and the public order of the European Union. Oxford: Oxford University Press.

Miaskowska-Daszkiewicz, Katarzyna. 2017. „Prawne instrumenty wspierające bezpieczeństwo epidemiczne biorców ludzkich komórek, tkanek i narządów". Studia Prawnicze KUL 3: 69-89.

Misztal, Henryk. 2011. „Konstytucyjne gwarancje wolności sumienia i religii”. W: Artur Mezglewski, Henryk Misztal, Piotr Stanisz, Prawo wyznaniowe, 66-73. Warszawa: Wydawnictwo C.H. Beck.

Morawski, Filip. 2020. „Zakaz przemieszczania się w związku z pandemią COVID-19 w świetle konstytucyjnego prawa do poruszania się". Przegląd Prawa Publicznego 9: 7-17.

Olszówka, Marcin, Konrad Dyda. 2020. „Analiza konstytucyjności ograniczeń w korzystaniu z wolności religii podczas pandemii koronawirusa w Polsce". Studia z Prawa Wyznaniowego 23: 441-469.

Ożóg, Michał. 2015. „Regulować czy deregulować swobodę przekonań religijnych, światopoglądowych i filozoficznych w życiu publicznym? Rozważania na tle art. 25 ust. 2 Konstytucji Rzeczypospolitej Polskiej z 2 kwietnia 1997 r." Przeglad Prawa Wyznaniowego 7: 101-112.

Ożóg, Michał. 2016. „Wolność sumienia i religii w stanach nadzwyczajnych w polskim systemie prawnym". Forum Prawnicze 4: 48-67.

Piechowiak, Marek. 2009. „Klauzula limitacyjna a nienaruszalność praw i godności”. Przeglad Sejmowy 2: 55-77.

Pietrzak, Michał. 2013. Prawo wyznaniowe. Warszawa: Wydawnictwo Prawnicze LexisNexis.

Ruczkowski, Piotr. 2012. „Decyzja w sprawie zakazu zgromadzeń publicznych jako przykład reglamentacji administracyjnoprawnej wolności i praw jednostki”. Przeglad Sejmowy 2: 79-104.

Sroka, Tomasz. 2020. „Ograniczenia praw i wolności konstytucyjnych oraz praw pacjenta w związku z wystąpieniem zagrożenia epidemicznego". Palestra 6: 75-98.

Stanisz, Piotr. 2017. Religion and Law in Poland. Kluwer Law International. 
Stanisz, Piotr. 2021. „Ograniczenia wolności kultu religijnego w czasie pandemii COVID-19: między konstytucyjnością a efektywnością". Przegląd Sejmowy 3: $143-165$.

Stańczuk, Izabela. 2020. „Ograniczenie wolności sumienia i religii w związku z wprowadzeniem stanu epidemii w Polsce”. W: Człowiek, Państwo, Kościót. Ksiegga jubileuszowa dedykowana Księdzu Profesorowi Arturowi Mezglewskiemu, red. Paweł Sobczyk, Piotr Steczkowski, 471-490. Lublin: Wydawnictwo Academicon.

Warchałowski, Krzysztof. 2004. Prawo do wolności myśli, sumienia i religii w Europejskiej Konwencji Praw Człowieka i Podstawowych Wolności. Lublin: Towarzystwo Naukowe KUL. 